\title{
Corruption and migration policy. EU crisis management revisited
}

\section{Larysa Sysoyeva}

Associate Professor, Sumy State University, Ukraine; Research Fellow, Alfried Krupp Wissenschaftskolleg, Greifswald, Germany

\section{Harald Kleinschmidt}

Professor em. Dr. phil. habil., Senior Fellow, Alfried Krupp Wissenschaftskolleg, Greifswald, Germany

(C) The Authors, 2017. This article is published with open access at ARMG Publishing.

\begin{abstract}
This study explores the analysis of the policy of EU countries regarding immigrants under the impact corruption may have had on the formulation and implementation of migration policies. The analysis shall proceed through three steps. First, authors shall describe our position within the theoretical discourse about corruption theory. Authors shall then move on to compare the shifts in levels of corruption in select EU Member States for some crucial years during the period between 2006 and 2015. Third, researchers shall look into the core factors behind these shifts and identify links to migration policies.
\end{abstract}

Keywords: refugee policy, migration, corruption.

JEL Classification: F5, F6, J16.

\section{Introduction}

Since the very beginning of the formation of the European integration project, the problem of refugees and forced migration has played a decisive role for the EU and its Member States.

While formulating the task of creating the common European economic space based on four market freedoms (free movement of goods, services, capital and labor), the EU founders predicated the envisaged process upon the legal regulation of workers' and professionals' employment and also the provision of appropriate social services. Since the creation of European integration structures, migration has been divided into internal (within Member States and between EU Member States) and external processes (related to external migration and mode of entry, exit and residence for foreigners). The impact of migration factors on political processes in the countries of EU has increased substantially due to the growth of numbers of refugees and the emergence of some powerful refugees' communities in most countries in Western and Southern Europe. These events have led to the complication of the social and demographic structure of European societies and put on the agenda several issues, namely, the question of limitation the number of refugees to the European Union, the question of entering into an equal commitment by the countries of EU, the question of refugees' adaptation to host societies. These problems include several aspects, including the demand to develop more elaborate political, legislative and administrative tools designed to facilitate the solution of refugee problems.

According to official European statistics the number of refugees in the EU began to increase in 2010 by $600 / 000$ people for a five year period and increased maximally to 300.000 people up to the summer of 2015 . It should be noted that since 2012 the number of Syrian refugees in the EU has increased more than 30 times: 234,000 as of 31.12.2012 and 799.900 as of 31.12 2015. In 2015 the number of international migrant stock in West Europa as a percentage of the total population was 14.4. An increase of the refugee intensity to the EU, in consequence of global problems, significantly worsened the attitude to this problem among politicians of European countries and the need to implement policy changes. Moreover, as military action in Syria and Afghanistan intensified, the question of the distribution of immigrants in the European Union turned acute, as excessive strains on Italy and Greece allowed applying ch. 3 of Art. 78 of the Treaty of Lisbon. This article provides that in case if one or more Member States are faced with an emergency situation related to the accumulation of the third country citizens, the European Council, upon proposal by the European Commission, may take precautionary measures.

The EU has developed the principle of quota distribution of migrants based on the following indicators: population of Member States (40\%), the total GDP (40\%), the number of applications for obtaining refugee status during the 2010-2014 year (10\%), unemployment rate (10\%). The Commission has set an ambitious goal to 
take part in the displacement program necessarily for all member states, except the UK and Ireland, which have the right to refuse participation in the distribution of migrants according to notification of European treaties. Denmark, in accordance with notification to the Lisbon Treaty, will also not take part in the distribution.

In order to prevent refugee movement from southern to northern EU countries the European Commission has proposed to implement resettlement only on condition that the refugee acts in accordance with the prohibition to change the country of initial residence during a period of five years and also to deny to refugees the possibility of legalization in other EU countries and access to social rights.

It was supposed that migrant reception will be followed by a certain flow of money. This initiative would encourage Member States to be more compliant, but initially it encountered to the resistance of some countries. At present the program of displacement has been stalled, even despite the fact that Germany is ready to accept additional obligations on increasing their quotas. For the so-called new Member States, the quota principle of distribution of refugees means a significant increase of the number of migrants. That is why many of them reject that mechanism trying to add their subjective indicators to the indicators proposed by the European Council. Thus, Poland insists on considering humanitarian aid that deals with the events in the East of Ukraine. Hungary and the UK explicitly refused to accept migrants. France, Poland, the Baltic States, the Czech Republic and Slovakia appealed to additional consultations.

\section{Literature review}

Corruption as defined within WGI is a broadly conceived concept, essentially associated with political issues. In corruption theory, political corruption has long been ranked as a significant factor of the legitimacy, understood as rule justification capacity (Beetham, 1991, pp. 69-89), of institutional actors credited with the capability of making authoritative decisions for collectives, mainly state populations (Manow, 2003; Wolf, 2014, p. 16). However, theorists have ascribed changing values to the impact corruption has had on the making and implementation of public policy, specifically with regard to economic and social issues. During the 1960s, these impacts had been contextualized with modernization and assessed as an overall positive contribution to economic growth and the maintenance of socio-political stability, and this assessment had been defended with pragmatic arguments such as the observation that corrupt government officials may work harder and be more open to innovations than non-corrupt officials (Leff, 1964; Huntington, 1968). By contrast, more recent theorists have condemned this assessment as irresponsible due to its immanent support for the toleration of criminal practices (Jansen/Priddat, 2005, p. 7), the imposition of a strict separation of the public from the private sphere (Theobald, 1990) and the generation of an unwarranted optimism regarding unascertained positive links between corruption and economic growth (Shleifer, 1993). Beyond this shift in value ascription, even critical corruption theorists have continued to assume that levels of corruption should be seen as correlated with levels of development and that, by consequence, levels of corruption decline with enhanced economic growth, even though the correlation between both levels has not been verified upon empirical data (Abed/Gupta, 2002; Bardhan; 1997; Schefczyk, 2005). The lack of salience of this hypothesis is further revealed in data issued by the European Anti-Fraud Office (OLAF), which has recorded growth in the number of fraudulent practices reported within the EU since 2004 (Frankfurter Allgemeine Zeitung, 27 April 2004) and has increased the number of its recommendations to state prosecutors for compensation for such practices from 175 in 2008 to 364 in 2015 (OLAF 2011, p. 19; 2015, p. 20), covering a total of financial demands for recovery of over 3 billion EUR for the period between 2010 and 2015 (OLAF, 2016) and 988.1 million EUR for 2015 alone (OLAF, 2015, p. 20).

\section{Methods}

From the point of view of the current state of the refugee problem in the European Union the existing policy of refugee distribution in EU countries in our study can be regarded within the following perspectives:

$>$ in the context of interinstitutional relations within the EU and between EU institutions and governing bodies of its member countries;

$>$ in the level of political relations and debates on policy direction and regulation of refugees within the Home and Justice pillar of the EU;

$>$ in terms of strengthening the role of refugee problems in the implementation of the Common Foreign and Security Policy of the Union. 
In order to study this question, we will explore the relationship among control levels over corruption in the countries of EU with existing tools of refugee regulation and internal policy of the countries in EU regarding refugees.

We will take the indicator that reflects the control level over corruption from the site The Worldwide Governance Indicators (WGI).

The methodology of calculating the control of corruption is presented in The Worldwide Governance Indicators: Methodology and Analytical Issues Draft Policy Research Working Paper.

The WGI cover over 200 countries and territories, measuring six dimensions of governance starting in 1996: Voice and Accountability, Political Stability and Absence of Violence/Terrorism, Government Effectiveness, Regulatory Quality, Rule of Law, Control of Corruption.

\section{Results}

The data reflect the views on governance of survey respondents and public, private, and NGO sector experts worldwide. According to Control of Corruption data - capturing perceptions of the extent to which public power is exercised for private gain, including both petty and grand forms of corruption, as well as "capture" of the state by elites and private interests.

Figure 1 presents the characteristics of the control level over corruption in the countries of EU:

$>3$ countries have the average over the all years of calculation rate from $-0.5 \leq \mathrm{SS} \leq-0$. They are: Bulgaria, Croatia and Romania;

$>11$ countries from $0 \leq \mathrm{CC} \leq 1$. They are: the Czech Republic, Estonia, Greece, Hungary, Italy, Latvia, Lithuania, Malta, Poland, the Slovak Republic and Slovenia;

$>5$ countries from $1.0 \leq \mathrm{CC} \leq 1.5$. They are: Belgium, Cyprus, France, Portugal, Spain;

$>9$ countries from $1.5 \leq \mathrm{CC} \leq 2.5$. They are: Austria, Denmark, Finland, Germany, Ireland, Luxembourg, the Netherlands, Sweden and the United Kingdom.

Thus, the "old" EU Member States compared to the "new" Member States of the EU have higher values.

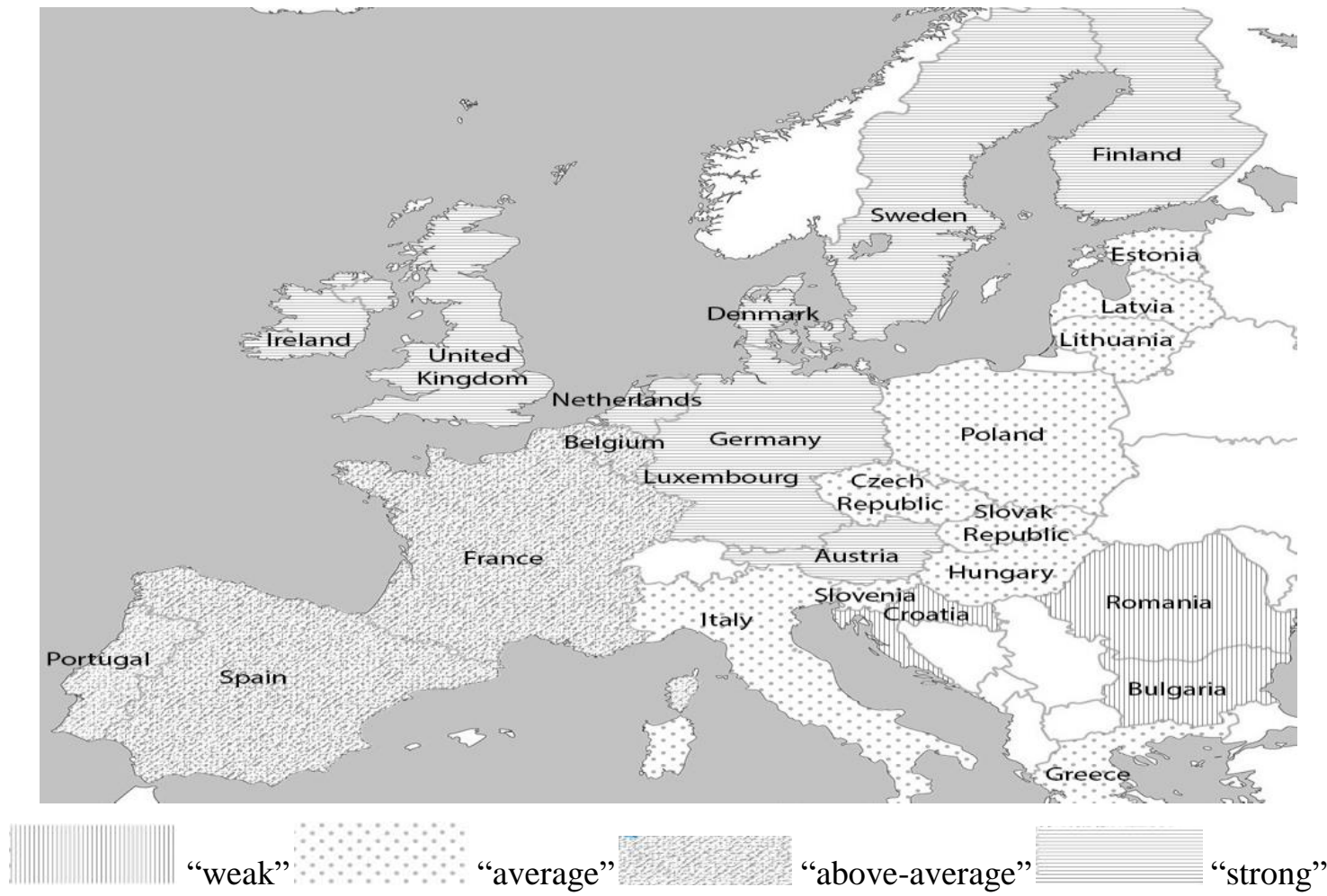

Source: authors' elaboration on the The Worldwide Governance Indicators.

Figure 1. The control level over corruption in the countries of EU-28

These figures not only demonstrate the dramatic increase in the level of corruption within the EU but are also closely paralleled by WGI data featuring an equally dramatic decline of corruption control in the EU as a 
whole as well in most EU Member States forming Group 2 in Table 1 between 2006 and 2012 (the Czech Republic, Greece, Hungary, Italy, Latvia, Lithuania, Malta, Poland, the Slovak Republic). This group comprises seven of the ten countries admitted to the EU in 2004, together with Greece (admitted in 1995) and Italy (one of the founding members). All these countries were gravely affected by the EU-wide slump in GDP between 2008 and 2009, averaging an EU-wide decline of 4,5\% from, peaking in Malta (-14.8\%) and Greece (-14.1\%), showing high figures for Lithuania (-7.7\%), Italy $(-6.8 \%)$ as well as Latvia $(-5.5 \%)$ and moderate ones for the Czech Republic (-4.5\%) as well as Hungary (-3.1\%) during the same period (Eurostat, 2016).

Table 1. Estimate of control of corruption (ranges from -2.5 (weak) to 2.5 (strong)) (fragment)

\begin{tabular}{|c|c|c|c|c|c|c|c|c|}
\hline & 2006 & 2007 & 2008 & 2009 & 2010 & 2011 & 2012 & Average* \\
\hline Austria & 1.99 & 2.11 & 1.92 & 1.76 & 1.63 & 1.44 & 1.36 & 1.82 \\
\hline Belgium & 1.25 & 1.30 & 1.32 & 1.43 & 1.49 & 1.56 & 1.56 & 1.43 \\
\hline Bulgaria & -0.10 & -0.23 & -0.30 & -0.25 & -0.21 & -0.22 & -0.24 & -0.22 \\
\hline Croatia & 0.09 & 0.08 & -0.04 & -0.10 & -0.03 & 0.01 & -0.04 & -0.03 \\
\hline Cyprus & 1.09 & 1.08 & 1.24 & 0.93 & 1.00 & 0.89 & 1.25 & 1.14 \\
\hline The Czech Republic & 0.31 & 0.23 & 0.27 & 0.33 & 0.26 & 0.30 & 0.23 & 0.34 \\
\hline Denmark & 2.55 & 2.53 & 2.47 & 2.52 & 2.41 & 2.45 & 2.40 & 2.42 \\
\hline Estonia & 0.96 & 0.92 & 0.87 & 0.91 & 0.86 & 0.93 & 0.99 & 0.86 \\
\hline Finland & 2.56 & 2.48 & 2.41 & 2.30 & 2.18 & 2.22 & 2.23 & 2.36 \\
\hline France & 1.46 & 1.44 & 1.38 & 1.42 & 1.44 & 1.52 & 1.43 & 1.37 \\
\hline Germany & 1.79 & 1.70 & 1.73 & 1.72 & 1.74 & 1.71 & 1.79 & 1.84 \\
\hline Greece & 0.35 & 0.25 & 0.10 & 0.01 & -0.16 & -0.18 & -0.25 & 0.21 \\
\hline Hungary & 0.61 & 0.56 & 0.38 & 0.34 & 0.25 & 0.32 & 0.28 & 0.45 \\
\hline Ireland & 1.72 & 1.75 & 1.76 & 1.77 & 1.70 & 1.54 & 1.46 & 1.59 \\
\hline Italy & 0.46 & 0.31 & 0.25 & 0.13 & 0.00 & 0.08 & -0.02 & 0.26 \\
\hline Latvia & 0.29 & 0.25 & 0.13 & 0.13 & 0.13 & 0.19 & 0.16 & 0.10 \\
\hline Lithuania & 0.08 & 0.03 & 0.04 & 0.12 & 0.27 & 0.24 & 0.32 & 0.21 \\
\hline Luxembourg & 1.91 & 2.01 & 2.02 & 1.99 & 2.06 & 2.17 & 2.14 & 2.00 \\
\hline Malta & 1.05 & 1.06 & 1.04 & 0.83 & 0.85 & 0.83 & 0.97 & 0.89 \\
\hline The Netherlands & 2.08 & 2.22 & 2.16 & 2.17 & 2.18 & 2.16 & 2.14 & 2.12 \\
\hline Poland & 0.17 & 0.19 & 0.35 & 0.37 & 0.41 & 0.49 & 0.59 & 0.42 \\
\hline Portugal & 0.97 & 0.96 & 1.00 & 1.04 & 1.03 & 1.08 & 0.93 & 1.08 \\
\hline Romania & -0.16 & -0.18 & -0.16 & -0.27 & -0.22 & -0.19 & -0.26 & -0.25 \\
\hline The Slovak Republic & 0.40 & 0.30 & 0.30 & 0.23 & 0.24 & 0.24 & 0.07 & 0.23 \\
\hline Slovenia & 1.02 & 0.98 & 0.91 & 1.02 & 0.85 & 0.90 & 0.82 & 0.91 \\
\hline Spain & 1.12 & 0.99 & 1.11 & 1.00 & 1.01 & 1.05 & 1.06 & 1.07 \\
\hline Sweden & 2.21 & 2.25 & 2.23 & 2.29 & 2.32 & 2.22 & 2.32 & 2.25 \\
\hline The United Kingdom & 1.79 & 1.72 & 1.66 & 1.60 & 1.56 & 1.58 & 1.65 & 1.85 \\
\hline
\end{tabular}

Notes: *aaverage from 1996 to 2015.

Source: authors' calculations on The Worldwide Governance Indicators (1996-2015).

The plummeting of GDP data for the EU as a whole and for many of Group 2 Member States fell together with the financial crisis and the Lehman shock, hitting these countries while corruption was already advancing. During the period between 2008 and 2010, corruption control figures further declined from +0.25 (2007) to 0.16 (2010) for Greece, from +1.06 (2007) to +0.83 (2010) for Malta, from +0.56 (2007) to +0.25 (2010) for Hungary, from +0.31 (2007) to 0.00 (2010) for Italy, from +0.25 (2007) to +0.13 (2010) for Latvia, from +0.30 (2007) to +0.24 (2010) for the Slovak Republic, with no significant changes taking place in the Czech Republic, Estonia and Slovenia and a slight increase in corruption control figures recorded for Poland and Lithuania (see Table 1).

The Lehman shock revealed that US Congress and the Federal Government, the European Commission and the governments of EU Member States were taken by surprise, even though they acted swiftly from October 2008. However, by that time, more than a decade had passed since the Asian Financial Crisis, without any 
precautionary action having been taken outside East and Southeast Asia and without the anticipatory formulation of strategies for the case that similar disturbances might reoccur elsewhere in the world (Kotegawa, 2013). Hence, in fall 2008, institutions of governance in the EU and its Member States were compelled to respond to the crisis without any proactively conceived strategy. In line with empirical historical data (Engels, 2009), we interpret the weakening of corruption control in EU Member States as an indicator for the declining legitimacy of institutions of governance, as defined above, once their lack of capability for anticipating precautionary action has been revealed. In other words, we argue that occurrences hitting institutions of governance unprepared, result in the weakening of their legitimacy and, in turn, the imposition of restrictions upon the actorship capability of these institutions.

When, during the second half of 2015, the immigration crisis took place in Europe and resulted in mass migration out of West Asia, targeted, first, at Greece and Italy and subsequently reaching countries north of the Alps, institutions of governance in the EU and its Member States were equally unprepared. As late as in May 2015, the European Commission published its European Agenda on Migration (European Commission, 2015), a document designed to explicate the Commission's stance on immigration policy. Although, at this time, the military conflict in Syria had been ongoing for four years, forcing several millions of Syrian nationals out of their country and into neighboring Jordan, Lebanon and Turkey, the document completely failed to consider emigration from Syria into the EU as a possible occurrence and, instead, focused on emigration from SubSaharan Africa mainly into Italy via the Mediterranean Sea. Obviously, this focus was mandated by news about dramatic situations in the course of which migrants had died while crossing the Mediterranean Sea. Also, the European Commission felt obliged to present a key to the solution of the problem of controlling continuing migration on EU territory from Italy to other Schengen states. However, despite these urgencies, the document revealed the complete lack of any awareness on the side of the European Commission that largescale migratory movements were taking place in West Asia at the time and might spill over onto EU territory.

Consequently, within the short period of seven years, the EU and its Member State governments were twice caught unprepared in turmoil, in which strong legitimate actorship capabilities of institutions of governance would have been required. The first case of the financial crisis and the Lehman shock boosted the trend towards both the increase in the level of corruption and the decline of corruption control and, in turn, restricted actorship capabilities. When the second case occurred, institutions of governance in the EU and its Member States were at a loss to demonstrate their capability of regulating the migration process to the degree that the enforcement of human rights, the Geneva Convention Relating to the Status of Refugees, and EU as well as Member State immigration law would have demanded. Hence, we expect that the level of corruption will further increase in the EU.

\section{Conclusion}

Authors conclude that the correlation between corruption and migration policy is indirect, intermediated through the pressure that inapt crisis management issues upon the legitimacy of institutions of governance. Researchers posit that shifts in the level of corruption and corruption control are indicators for shifts in the actorship capabilities of these institutions. The more often institutions of governance have to cope with a manifest record of poor performance in crisis management, the higher is the likelihood that their legitimacy wanes and that, by consequence, actorship capabilities become restricted. Conversely speaking, only institutions of governance with well-ascertained legitimacy have a chance of regulating migration effectively at times of crises and in accordance with human rights and international law.

\section{Recommendations}

Authors recommend, first, that fighting corruption should be contextualized not just with strategies of boosting economic growth but also with issues pertaining to the legitimacy of institutions of governance. Both in theoretical terms and in practical terms of policy formulation and implementation, corruption should be defined, considered, controlled and combatted as a multi-dimensional evil, the damages of which go well beyond quantitative monetary detriments and strain core factors of state stability. Second, it is recommended that institutions of governance use their substantial information gathering capacities to formulate proactive policies apt to enhance actorship capabilities for crisis management with the prospect of establishing positions, from out of which these institutions can have a chance of handling crises swiftly and effectively rather than corresponding reactively. The two cases discussed in this paper provide sufficient evidence relating to the two crises that hit European institutions of governance in 2008 and 2015. They show that sufficient information 
was available for use but remained un- or underutilized for proactive policy-making. Third, authors recommend that, once institutions of governance already find their legitimacy reduced and actorship capabilities restricted in ongoing crises due to corruption and ensuing lack of the effectiveness of policy formulation and implementation, they should be given the opportunity to combine efforts to restore or at least stabilize their own actorship capability domestically with the fulfilment of international obligations. In the specific case of the immigration crisis of 2015/2016, the European Commission and the European Council might have been better advised to at least temporarily waive the majority rule with regard to Justice and Home Affairs rather than putting pressure on governments of those EU Member States, whose governments were finding it difficult to implement EU rules.

\section{References}

1. Abed, George T., Sanjeev Gupta (2002). The Economics of Corruption, in: Abed, Gupta, eds., Governance, Corruption and Economic Growth (Washington, D.C.: IMF), pp. 1-16.

2. Bardhan, Pranat (1997). Corruption and Development. Journal of Economic Literature, 35, 1320-1346.

3. Beetham, David (1991). The Legitimation of Power. Basingstoke: Macmillan.

4. Engels, Jens Ivo, Andreas Fahrmeir, Alexander Nützenadel, eds. (2009). Geld - Geschenke - Politik. Korruption im neuzeitlichen Europa. Historische Zeitschrift, Beihefte, N. F., 48. Munich: Oldenbourg.

5. European Commission (2015). A European Agenda on Migration. COM (2015) 240 Final (Brussels, 13 March 2015).

6. European Commission. Refugee Crisis: European Commission takes decisive action. Resource document. - Press release. Retrieved from http://europa.eu/rapid/press-release_IP-15-5596_en.htm.

7. European Union (2009). Treaty of Lisbon. http://www.lisbon-treaty.org.

8. Eurostat. Asylum and managed migration. Resource document. Eurostat. Database. Retrieved from http://ec.europa.eu/eurostat/web/asylum-and-managed-migration/data/database.

9. Eurostat (2016). BIP data. Retrieved from http://ec.europa.eu/eurostat/web/.

10. Frankfurter Allgemeine Zeitung (27 April 2004). Report on OLAF data.

11. Huntington, Samuel Paul (1968). Political Order in Changing Societies. New Haven: Yale University Press.

12. Jansen, Stephan A., Birger P. Priddat (2005). Vorwort, in: Jansen, Priddat, eds., Korruption. Unaufgeklärter Kapitalismus, 7-10. Wiesbaden: Verlag für Sozialwissenschaften.

13. Kaufmann, Daniel, Aart Kraay, Massimo Mastruzzi (2010). The Worldwide Governance Indicators: Methodology and Analytical Issues. World Bank, September, 2010. IMF. Working Paper. WP/September.

14. Kotegawa, Daisuke (2013). The Lost Two Decades of the EU and USA? in: Executive Intelligence Review, 26 April 2013. Retrieved from www.larouchepub.com/other/2013/4017eu usa lost decades.html.

15. Leff, Nathaniel (1964). Economic Development through Bureaucratic Corruption, in: American Behavioral Scientist, 8-14.

16. Manow, Philip (2003). Politische Korruption als Gegenstand der Politikwissenschaft, in: Hans Herbert von Arnim, ed., Korruption. Netzwerke in Politik, Ämtern und Wirtschaft. Munich: Droemer Knaur.

17. OLAF (2011). European Commission, European Anti-Fraud Office, $12^{\text {th }}$ Report (2011); $16^{\text {th }}$ Report (Brussels: OLAF, 2015).

18. OLAF (2015). European Commission, European Anti-Fraud Office, $16^{\text {th }}$ Report (Brussels: OLAF2015).

19. OLAF (2016). Recommendations for recovery for fraudulent practices. Retrieved from https://ec.europa.eu/anti-frau/investigations/fraud-figures.en.

20. Schefczyk, Michael (2005). Paradoxe Korruption, in: Stephan A. Jansen, Birger P. Priddat, eds., Korruption, 103-122. Wiesbaden: Verlag für Sozialwissenschaften.

21. Shleifer, Andrei, Robert Vishny (1993). Corruption, in: Quarterly Journal of Economics, 109, 599-617.

22. Theobald, Robin (1990). Corruption, Development and Underdevelopment. Basingstoke: Macmillan; Durham, NC: Duke University Press.

23. Wolf, Sebastian (2014). Korruption. Antikorruptionspolitik und öffentliche Verwaltung. Wiesbaden: Verlag für Sozialwissenschaft.

24. The Worldwide Governance Indicators. Access the WGI data at www.govindicators.org. 